CSABA VARGA*

\title{
Differing Mentalities of Civil Law and Common Law? The Issue of Logic in Law
}

\section{Mentality and Legal Culture}

In recent-day comparative literature, the term of mentalités juridiques is being used as the key through which the underlying basic difference between Civil Law and Common Law can be best shown. ${ }^{1}$ This term is to englobe the entire view within which law is conceived at all, is named and also put in whatever intellectual context. So it affords one of those paths or aspects for an approach that may be instrumental for a comparative investigation of legal cultures in general and the dilemma of their future convergence or divergence in particular. ${ }^{2}$

\section{Naming of Basic Units in a Normative Stuff}

From the wide range of linguistic expressions and other objectifications used in the direction of behaviour, ${ }^{3}$ the dilemma of rule and/or norm is not a scholarly issue in any direct sense. Neither the dilemma nor its resolution can

"Scientific Adviser, Institute for Legal Studies of the Hungarian Academy of Sciences, H-1250 Budapest, P.O. Box 25; Professor at the Pázmány Péter Catholic University of Hungary, Director of its Institute for Legal Philosophy, H-1428 Budapest 8, P.O. Box 6. E-mail: varga@jog.mta.hu

1 An expression by Pierre Legrand.

2 Cf. Varga, Cs.: Comparative Legal Cultures? Renewal by Transforming into a Genuine Discipline. Acta Juridica Hungarica 48 (2007) 2, 95-113 and Legal Traditions? In Search for Families and Cultures of Law. Acta Juridica Hungarica 46 (2005) 3-4, 177-197.

3 To quote just one author from the rich international literature covering the topic, Opałek, K.: Theorie der Direktiven und der Normen. Wien-New York, 1986, 88 lists norms, rules and principles, alongside with persuasion, wish, proposal, request, supplication, advice, warning, as well as recommendation and encouragement, as directions of behaviour. In such a broad sense, see, from the Hungarian literature, Szotáczky, M.: A normák eredete és funkciója (Genese und Funktion der Normen). In: Ádám, A. (ed.): Tanulmányok Szamel Lajos tiszteletére. Pécs, 1989. 227-238. 
in fact be derived either from the historical etymology of the relevant words or from investigations into the history of basic legal ideas, inspiring or merely reflecting one or another language use. Clear-cut distinctions of meanings regarding these two terms are not even specified either by various historical periods or by the historical cultures of law and legal thought developed in a diversity so far. Although their regular usages may be different compared to each other, in most attempts at a theoretical definition they are still decisively referred to as synonyms, ${ }^{4}$ as concepts able to substitute each other nearly completely. ${ }^{5}$ Therefore the issue whether one or another usage is preferred by a given language and underlying culture depends for the most part on mere habits of parlance. However, such habits may then (through the latently creative and socially constructive force of the consolidated and consolidating usage of language) get organised into certain (historically self-solidifying) blocks. And from then on, these blocks may in their own manners generate additional meanings, with specifications according to contexts, which may on their part also eventually lead to kinds of separation providing some basis for added theoretisation.

\section{Terms of 'Rule' \& 'Norm'}

The term 'rule' ['règle', 'Regel', 'regola', 'regla'] originates from the Latin 'regula', while 'norm' stems from the Latin 'norma' as used to denote a tool applied by masons and carpenters in ancient Rome to draw the "carpenter's square". ${ }^{6}$ Or, "A regula, or rule, is used to draw straight lines.", and "A norma is used to make right angles." That is, "The carpenter's norms and rules (meaning

4 For instance, "The rule is a synonym for 'norm' or 'directive' taken as the declaration of a prescriptive function.”-writes W[róblewski], J.: Règle. In: Arnaud, A.-J. (dir.): Dictionnaire encyclopédique de Théorie et de Sociologie juridique. Paris, 1988, 346. An even simpler solution is proposed by the basically American The Philosophy of Law An Encyclopedia. New York-London, 1999, with the entry 'Rule' referred to-but speaking about nothing but-'Norms' eventually.

5 This is illustrated by the way how in case even of an otherwise minutely precise author-e.g., Pavčnik, M.: Pravno pravilo. Zbornik znanstvenih razprav [Ljubljana] (1995), 217-240 and in his Die Rechtsnorm. Archiv für Rechts- und Sozialphilosophie 83 (1997) 4, 463-482-, one term is simply replaced by the other when changing between Slovenian and German languages. For a Hungarian and German inter-change, see also Peschka in note 30.

${ }^{6}$ Online Etymology Dictionary <http://dictionary.reference.com/browse/norm $>$. 
the tools) make right-norms make orthogonal and rules makes straight-that which they shape."7

In its present sense, 'norm'-mostly in derivatives such as 'normal, 'normality', etc.-is a product of $19^{\text {th }}$-century development, differentiating and homogenising human conditions as well as social processes and attitudes of production, for adjusting them to previously set standards. To denote nothing but 'standard', the term 'norm' was first used in pedagogy, and then, in health care, and only later on, in the course of the same century, it got also extended to standardisation in production and technology, for that phases and successive steps of the same industrial processes can be isolated, defined, combined and re-organised as a series of distinct patterns. ${ }^{8}$

Let us mention as an illustrative example of incidentalities in the history of the usage of words that, in its original meaning, 'rule' once served-instead of the causal succession meant by the expression of "if [...], then $[\ldots]$ ", implying conditional repetition firstly describing, and then, partly prescribing those facts which may in their conceptual generality constitute a case, and partly also ascribing a sanction to them-to express some basic backgrounding wisdom or synthesising adage, summarising the versatility of Roman jurisprudents indefatigably searching for the principles of a justifiably right-and preferredly exclusively right-solution. ${ }^{9}$

According to its philosophical definition, the rule is a "formula indicating or prescribing what is to be done in a certain situation", noting in this very context that its prescriptive use affords a criterion with selective force and that no such use shall be overshadowed by those recently spread constative uses which aremostly as connected with the senses of 'regular/irregular', or 'regularity', and so on-worded as if they were merely descriptive. ${ }^{10}$

On the other hand, norm is the "concrete type or abstract formula of what has to be done, at the same time including a value judgement in the form of some kind of ideal or rule, aim or model", adding to the definition above that

7 Pattaro, E.: The Law and the Right A Reappraisal of the Reality that Ought to be. Dordrecht, 2007, 62.

${ }^{8}$ See, e.g., Foucault, G.: Surveiller et punir. Paris, 1975, 186 and Canguilhem, G.: Le normal et le pathologique $4^{\mathrm{e}}$ éd. Paris, 1979. 175.

9 For more details, see Varga, Cs.: A jogi gondolkodás paradigmái. $2^{\text {nd }}$ ed., Budapest, 2004. 33-34, enlarging explanations he afforded in his Lectures on the Paradigms of Legal Thinking. Budapest, 1999.

${ }^{10}$ Lalande, A.: Vocabulaire technique et critique de la philosophie [1926], Paris, 1991, 906-907. According to Ota Weinberger's similar (and somewhat simplifying) formulationin his The Role of Rules. Ratio Juris 1 (1988) 3, 224-240, especially para. 1, 225.-, "Rules are advice to be used in determining action." 
norms are mostly formulated in order to express some logical thought or act of will, or free representation, or emotion or ideal of beauty. ${ }^{11}$

When, accordingly, norm is taken as "synonym of "rule" " (with the latter regarded as somewhat "more general" 12 or "more wide and generic"13), it is remarkable that in everyday usage the rule is still primarily an explicit or posited formulation-as the in-itself neutral and historically accidental outcome-of some 'rule-enactment' or 'regulation', while the norm is either the logical (i.e., logified) form of the above or the logical (and normative) prerequisite of the act of regulation itself.

This explains why 'rules' may either be ones of experience ${ }^{14}$ or, specifiedly, ones of a game, e.g., of the law (expressed as Spielregeln \& Rechtsregeln). All this is unproblematic so far as we are only interested in them as the manifestation of (or access to) something else, taken as more basic. As to its apparent pair, 'norms' enter the scene when the rule's intended or probable notation becomes problematic and requires further investigation in a way that out of the rule as the presentation of something made accessible to us, we start searching for gaining an identifiable message by means of the former's logical (etc.) analysis.

It is surely not for mere chance that we can hardly speak of, for instance, 'creation of norms'; and we only speak of 'provision of norms' when we intend to emphasise either the field as being "normed" (ordained under regulation) or the artificiality of the said regulation. Notwithstanding, present-day literature suggests the idea as if the norm separated out of the rule by its mere linguistic formulation as a logical proposition. Actually, however, it is not the rule but the norm alone that is considered and also treated in an onto-epistemological (and, alongside with it, also psychological and logical, etc.) perspective, in order to be able to interpret it both as an enunciation ${ }^{15}$ and as the contents of denotation (inherent, among others, also in a psychologically examinable act of will). ${ }^{16}$

That what has been explicated above seems to be substantiated by the fact that while in English language, for instance, historical dictionaries specify

${ }^{11}$ T[roper], M. \& L[ochak], D.: Norme. In: Dictionnaire encyclopédique... [note 4], 691.

${ }^{12}$ E.g., Perrin, J.-F.: Règle. In: Archives de Philosophie du Droit 35: Vocabulaire fondamental du droit. Paris, 1990, 245-255.

${ }^{13}$ Borsellino, P.: Norms. In: The Philosophy of Law An Encyclopedia [note 4], 596598, especially on 596.

14 Ibid.

${ }^{15}$ See, above all, Alchourrón, C. E.-Bulygin, E.: Normative Systems. Wien-New York, 1971.

${ }^{16}$ See, primarily, Kelsen, H.: Allgemeine Theorie der Normen. Wien, 1979. 
more than twenty entries of meaning and fields of application for the usage of the single word 'rule', each of these are still related exclusively to the availability or prevalence of a given measure of behaviour, either indicating or just carrying and/or enforcing it, without any of them claiming even incidentally that the rule itself will serve as the denotatum (with the objectivation itself or its communication embodying for us this very measure either through its textuality and grammatical make-up or owing to-as reconstruable from-the logical interrelationship among its elements). ${ }^{17}$ Moreover, the pervasive strength of the English language mentality is excellently shown by the fact that not even the amazingly late and rather slow spread of the word 'norm' provoked any change. Namely in English, quite until linguistic (later on: linguisticological) analysis grew into the main trend of moral philosophising in the first decade of the $20^{\text {th }}$ century, the word 'norm' had exclusively been used to refer to some standard, pattern or measure made available, and by far not in order to imply that the standard, pattern or measure itself could have been embodied (objectified ${ }^{18}$ ) by it in a way that one and exclusively one single right meaning could be extricable from such an embodiment. ${ }^{19}$

In language use, we do not to talk about 'logic of rules' instead of 'logic of norms'. No way in everyday practice we do equate the two terms with each other. Only a 'logic of norms' can be thought of, as if accepting in advance

${ }^{17}$ The Compact Edition of the Oxford English Dictionary Complete Text Reproduced Micrographically, I-II. Oxford, 1971, 2599-2600. In incidences far away in the past, such examples may affirm this: "Peos riwle" [Ancren Riwle a (1225) \{2 (Camden Soc. 1853)\}] or "Pe pope [...] forsook Pe rule of Pe olde tyme" [John de Bartholomeus (de Glanvilla) Trevisa: Polychronicon Randulphi Higden (tr. 1387), VII, 431 \{Rolls series 1865-1867\}] (original edition of the Oxford English Dictionary, 881, column 3 and 882, column 1, respectively). Against the historically established use, it is exclusively the modern (and, in a linguistic sense, rarer) professional usage that can attribute the word such a meaning: "Either according to the rules of the common law, or by the operation of the Statute of Uses." Penny Cyclopadia of the Society for the Diffusion of Useful Knowledge (1842), XIX, 379/2, quoted by Oxford English Dictionary, 882, column 2.

${ }^{18}$ Obviously, this is a case of secondary objectification, i.e., one objectified by (through/in) previous objectification (copying the pattern of "secondary nature", built by humans for their servicing, upon the genuine nature as found and made use of on Earth). Cf., in a legal context, Varga, Cs.: 'Thing' and Reification in Law. In: Varga, Cs.: The Place of Law in Lukács' World Concept. Budapest, 1985, ${ }^{2} 1998$.

${ }^{19}$ It is to be noted that from 1676 on, the word appeared in the form of 'norma/normae', always italicised as a borrowance from the Latin, and started to spread as 'norm' only from 1885, albeit between 1821 and 1877 mostly in pairs of synonyms such as, e.g., 'norm or model', 'norm and measure' or 'norm or principle'. Ibid., 1942, respectively (as in the note supra) 207, column 3. 
that nothing but linguistic propositions conceived of (or prepared as to serve) as logical units can be subjected to either logical operation or any genuine linguistico-logical analysis.

\section{Variety of Denotations}

All this may lead us to the conclusion that in actual occurrences and according to a nominal definition, 'rule' and 'norm' denote the same, the former considered from the point of view of making it accessible (communicable) as a message and the latter from the one of logic, that is, as seen from the perspective of internal coherence and consequentiality of relevant contents. Yet, regarding either their genus proximum or differentia specifica, we have to realise that both their conceptual volume and extension will be different. For no norm can be found in a rule (or rules) but the mental reconstruction of its (their) message may generate one. Otherwise speaking, a rule may refer to a norm by forecasting the good chance that a norm can be reconstru(ct)ed through (as mediated by) it. For in itself, the rule is but a specific linguistic expression, while in logic an abstract logical relation is stated by the norm. Following this train of thought, we can also conclude that they are common in that, at least, none of them can stand by itself. A rule may come into being if thematised (expressed, declared, posited, enacted or promulgated, and so on) as such. And a norm may come to being in a somewhat reversed manner, namely, if a logical form is given to one or some of (parts of) the above in result of mental operations in intellectual (re)construction. All this notwithstanding, they are not and cannot be related as form and contents to one another. ${ }^{20}$ Moreover, they are not co-extensive either. After all, rules differing by language, culture, structure and expression (etc.) may be logified as expressing the same norm and the same rule (in case of intentional or unintentional ambiguity, or with omission of punctuation or misprint, etc.) may serve for the reconstruction of differing norms.

\footnotetext{
${ }^{20}$ For the Hegelian-cum-Marxian use of this terminology, cf. Varga, Cs.: Autonomy and Instrumentality of Law in a Superstructural Perspective. Acta Juridica Hungarica 40 (1999) 3-4, 213-235 and Heuristic Value of the Axiomatic Model in Law. In: Raimund, J.-Lothar, Ph.-Schweighofer, E.-Varga, Cs. (ed.): Rechtstheorieband In memoriam Ilmar Tammelo (25. Todestag / 90. Geburtstag). Münster, etc., 2007 [in preparation].
} 


\section{The Uniqueness of Civil Law}

In terms of what has been said above, it is the norm that has become the cornerstone of theoretical system-construction in our continentally rooted Civil Law, based upon the axiomatic inclination to logification. It is no mere chance that the construction of Kelsen's Pure Theory of Law as the form-giver of the continental legal arrangement ${ }^{21}$ is founded on the Grundnorm, as it builds the derivation of validity throughout the entire prevailing law and order either on direct logical or indirect linguistic (conceptual) inference [Ableitung]. Accordingly, the norm is conceived as a logical unit which has been generated through logical reconstruction and can be subject to further logical operation. Therefore it is by far no chance either that both the need for and the conceptual performance of a doctrinal study of the law-with the call for a meta-system strictly conceptualised and rigidly logified upon the law (taken as a body of texts thoroughly consistent as concluding from the law's very components ${ }^{22}$ )were formed within the sole domain of Civil Law. ${ }^{23}$ (It is to be noted too that a theory of norms serving as a Rechtsdogmatik can be erected with no concept of

${ }^{21}$ Cf. Varga, Cs.: Hans Kelsen, a kontinentális jogi gondolkodás formaadója [Kelsen as form-giver of the continental legal thought]. In: Cs. Kiss, L. (ed.): Hans Kelsen jogtudománya. Budapest, 791-804.

${ }^{22}$ For the law's systemic property, cf. Varga, Cs.: A kódex mint rendszer (A kódex rendszer-jellege és rendszerkénti felfogásának lehetetlensége) [The code as a system: the systemic character of the law and the unfeasibility of conceiving it as a system]. Állam-és Jogtudomány, XVI (1973) 2, 268-299, and for the chance, as well as science-philosophical and science-methodological aspects of the doctrinal study of law, cf. Varga, Cs.: Jogdogmatika, avagy Jurisprudentia és társai - tudományelméleti nézőpontból [Legal dogmatics, or jurisprudentia and so on in a science-theoretical perspective]. In: Jogdogmatika és jogelmélet. Konferencia (2006. november 10-11.) a Miskolci Egyetem és a Miskolci Akadémiai Bizottság rendezésében: Programfüzet, 3-7.

${ }^{23}$ The predominance of the analytical method in applied legal philosophy and the thoroughly constitutionalised doctrine of the law in recent decades may suggest a trend greatly changed by today. Hence, the preference to analysis comes from an external interest, and the elitist (libertine) development of such constitutionalism as achieved by the US Supreme Court with academic assistance (i.e., by non-elected fora) has not yet exceeded the impact once exerted by the German doctrine on the English legal thought during the second half of the $19^{\text {th }}$ century, which may have enriched Common Law in both theoretical interpretability and conceptualisation without, however, dissimilating it from its own traditions. 
rule implied, ${ }^{24}$ whilst a theory of rules dedicated to the law's phenomenal form can also be built upon the exclusive basis of norm-concepts. ${ }^{25}$ )

On the other hand, the culture of Common Law-which, instead of striving either for an exhaustive conceptual representation and textual embodiment (objectification) of the law, or re-establishing it according to axiomatic ideals, or also instead of reducing certainty of and security in law to logical deducibility from previously set propositions, focuses rather on the law's social and professional environment and the reliability of the former's responsible and responsive practice, on the rectifying medium of everyday experience and of feedbacks drawn from dilemmas of decision on the level of common sense as organically rooted in tradition, as well as on the force of social continuity able to framework both preservation and renewal in the law so far and in as much as it may be needed-does speak in terms of rules as an exemplification of the law, that is, as an accidental manifestation and incidental actualisation in situations when one has to declare what the law is actually. ${ }^{26}$

${ }^{24}$ Kelsen supplies an illustrative example by avoiding the use of 'rule' (except for the term 'rule of law' with 'rule' meaning just domination or control) in his final theory of norms [note 16].

${ }^{25}$ See below, note 30 .

${ }^{26}$ This is well illustrated by the flow of literature covering the variety of areas and aspects of an academic interest in law which, historically drawing from the classical heritage of Jewish and Roman Law to span up to the present-day Anglo-American approach, uses exclusively the term of 'rule' as a phenomenal designation. Cf., e.g., D. van der Merwe 'Regulae iuris and the Axiomatisation of the Law in the Sixteenth and Early Seventeenth Centuries' Tydskrif vir die Suid-Afrikaanse Reg (1987) 3, 286-302; Kalinowski, G.: L'interprétation du droit: ses règles juridiques et logiques. Archives de Philosophie du Droit 30: La jurisprudence, Paris, 1985, 171-180; Clanchy, M.: A Medieval Realist: Interpreting the Rules at Barnwell Priory, Cambridge. In: Attwooll, E. (ed.): Perspectives in Jurisprudence. Glasgow, 1977, 176-194; Campbell, I. D.: Are the Rules of Precedent Rules of Law? Victoria University College Law Review 4 (1956) 1, 7-27; Jackson, M.: Austin and Hart on Rules. Edinburgh Philosophy Journal (March 1985), 24-26; Rosenberg, I. M.-Rosenberg, Y. L.: Advice from Hillel and Shammai on How to Read Cases: Of Specificity, Retroactivity and New Rules. The American Journal of Comparative Law 42 (1994), 581-598; Frierson, C. A.: 'I Must Always Answer to the Law...' Rules and Responses in the Reformed Volost Court. The Slavonic and East European Review 75 (1997) 2, 308-334.

In contrast, even in hypothetical situations when some normative staff is expressed in a logifying context, one can mostly encounter a norm-concept to base explanations. Cf., e.g., Fikentscher, W.: Methoden des Rechts IV: Dogmatischer Teil, Tübingen, 1977, ch. 31, para. VIII: 'Die Fallnorm' and, in a particularly telling context, Hassemer, W.: Über nichtjuristische Normen im Recht. Zeitschrift für Vergleichende Rechtswissenschaft (1984), 84-105. 
Yet, in a reverse sense, if rule is unconceptualised (without ever conceptually related, analysed and/or classified to the depth), that is, if neither logical conceptualisation nor any systemic idea stands in a determinative manner behind the practical act of giving it a linguistic form, that is, of denomination, ${ }^{27}$ then it is to be doubted whether a Rechtsdogmatik can ever be erected upon such a scheme. For no doctrine on the internal connection and coherence and conclusion can be built without being based upon norms. ${ }^{28}$

If and in so far as the norm is logical a unit, the rule is nothing else than a kind of proposition. As to their respective environment, norms may stand both on their own and in a systemic context. On the other hand, rules do presuppose principles, standards and policies that can, without being rules themselves, demarcate the sphere of the said rules' relevance and/or applicability. ${ }^{29}$

It is for the "scientific" methodology of the doctrinal study of the law [legal dogmatics] to answer how and to which depth the unlimited (and in principle also illimitable) demand of logical correlation, consequence and coherence may (if at all) be complemented to with axiologically founded teleological considerations. Therefore, the introduction of either broader (socially sensitive) definitions (confronting, e.g., free-law movement to exegesis) or brand new aspects (by, e.g., teleological interpretation) in an established discourse within Civil Law may equally induce debates shattering the normativism's basic claim. In contrast, the a-scientific approach to law as paradigmatic of the regime of Common Law may openly admit that law can only cover (reach and challenge)

${ }^{27}$ Cf. Varga, Cs.: Codification à l'aune de troisième millénaire. In: Mélanges pour l'hommage de Monsieur le Professeur Paul Amselek (ed. Patrick Wachsmann et al.). Bruxelles, 2004. 745-766 and Codification at the Threshold of the Third Millennium. Acta Juridica Hungarica 47 (2006) 2, 89-117.

${ }^{28}$ A conclusion like this is facilitated by the unclarified English word usage and also by the fact that instead of any doctrinal study, it was the attempt at an axiomatical foundation of sciences-e.g., Moore, G. E.: Principia Ethica (1903) [cf. Varga, Cs.: Lectures on the Paradigms of Legal Thinking. Budapest, 1999, 120]-that became instrumental in developing the linguistic analysis of law in the Common Law world. This very fact has anticipated English legal analysis not to be based on the very law but on sample sentences either authorly hypostatised or-as the early criticism upon Herbert Lyonel Adolphus Hart's The Concept of Law had shown-although presented in a sociologising manner, yet actually constructed with no factual coverage whatsoever. Cf. Varga, Cs.: The Hart-Phenomenon. Archiv für Rechts- und Sozialphilosophie 91 (2005) 1, 83-95. For an exemplary elaboration, see Samuel, G.: Epistemology and Method in Law. Aldershot, 2003.

${ }^{29}$ Practically the entire oeuvre of Dworkin, R. M.-starting from his paper The Model of Rules. University of Chicago Law Review XXXV (1967)-serves just the explication of this. 
the field of practical reason, within which-perhaps to our continental astonishment-sober everyday considerations are used to be given preference.

\section{Ambivalence in Praxis}

In sum, the dilemma of "rule and/or norm" carries marks of ambivalence inherent in coupling linguistic conventionalisation with attempts at theoretical (logifying and analytical) system-building upon it. (As a merely practical outcome, it is to be noted that albeit the Hungarian professional language usually refers to-by naming-legal rules, yet once they are subject to conceptual operation in doctrine, they are also treated as legal norms. ${ }^{30}$ )

On the final analysis, both can be used as conceptually justified in their own place and within their own context, respectively. For words in any language are used instrumentally and according to established habits, while concepts are formed as mental representations according to homogenising requirements set up by the given theoretical outlook and framework.

All in all, we have thereby justified the moment of identity, ambivalence and duality inherent in the terminological dilemma of "rule and/or norm". Despite any remaining conceptual uncertainty, we may find it fortunate that scholarship developed in both German and Hungarian language cultures belongs to the orbit of Civil Law, which makes an explicit difference in theory between the mere act of signalling the fact that there is a normative message made available and the logically processed conceptual embodiment (objectification) of such a message.

${ }^{30}$ E.g., Peschka, V.: A jogszabályok elmélete [The theory of legal rules]. Budapest, 1979. theorises upon norms exclusively [testified by its German version strikingly entitled as Die Theorie der Rechtsnormen. Budapest, 1982], after an obviously similar solution was already resorted to by Asztalos, L.: Polgári jogi alaptan. A polgári jog elméletéhez [A fundamental doctrine of the theory of civil law]. Budapest, 1987. 